\title{
INNOVATIONS AND DEVELOPMENT
}

\author{
STATE FINANCIAL STABILITY \\ SUPPORTING CONTINUOUS \\ INNOVATIVE DEVELOPMENT
}

\author{
NATALIA DROZD, \\ NATAlia Pleshakova
}

Faculty of Economics,

Taras Shevchenko Kyiv National

University, Ukraine

JEL Classifications: F 36, G 28 UDC: 336.01

Keywords: Financial stability, Innovation development, Indicators for financial security, State support of innovation, Global competitiveness

\begin{abstract}
The nature and indicators of financial stability of the state are presented. An issue of innovative development of the state is considered, its main difficulties and contradictions are defined. Trends and economic conditions for financial stability of the state in supporting innovation are substantiated. Special attention was paid to the factors to accelerate economic dynamics based on innovative mechanism, with appropriate set of direct financial, fiscal, legal, infrastructural, economic and political measures. It is proved that all the above measures are effective in their balanced unity under conditions of government providing with single framework for further innovative development.
\end{abstract}

http://dx.doi.org/10.15208/pieb.2013.06

Vol.13 (2), PP.5-11

Source: Drozd N., Pleshakova N., 2013. "State financial stability supporting continuous innovative development", Perspectives of Innovations, Economics \& Business, Vol.13(2), pp.5-11,

http://dx.doi.org/10.15208/pieb.2013.06

\section{Introduction}

"Stability" issue is fundamental in the global economy, due to the fact that without sufficient stability of national and international financial markets it is impossible to ensure economic growth and reliable functioning of financial sector. All of those originate from globalization, liberalization of foreign trade, weakening of state control and other particular reasonable factors. The impetus for research on financial stability began with financial crisis. The global financial crisis of over-reliance on emerging markets and external factors, as a result, led to a long and sharp economic recession.

Exhaustion of extensive factors of economic development causes permanent increased attention to finding with new factors in accelerating economic dynamics, which would be adequate for present state of the global economy. Advanced technologies, organizational decisions are increasingly determining 
economic success of the state, providing development and financial stability. Innovative processes significantly alter global markets.

Innovation is a complex process of transformation the newly generated ideas and knowledge into subject of economic relations. Developing innovations in transition of economy on an innovative way of development becomes essential. Both covering different aspects of the market economy (industrial, entrepreneurial, social, and technological) innovation process promotes growth of industrial production, increasing productivity, engaging new reserves in productive sectors.

\section{Theoretical provisions for financial stability}

Thus, Kallaur (2008) focuses on the fact that financial stability is characterizing a system that allows it to function in longevity without changing its structure and thus maintaining balance. He suggests including in "financial stability" the stability of bank institutions and non-bank financial intermediaries, financial markets and payment infrastructure, i.e. the entire financial system.

Kozyuk (2007) proposes the following definition: "a global financial stability means such level of the financial sector development that would promote longterm growth of the global economy as a whole, provided unrestricted funding deficits in balance of payments from private sources ... created a framework for prevention crisis situations in financial and banking, monetary and currency exchange areas ...".

Shinazi (2005) conducted several fundamental researches on financial stability. In his opinion, financial stability is a condition, under which the financial system is able to perform three key functions simultaneously:

1. Effectively and continuously contributes to inter-time allocation of resources in economy between savers and investors and distribution of economic resources in general

2. Allows evaluating future financial risks with acceptable accuracy, distributing and managing them effectively

3. Financial system is in such condition when it easily, if not continuously, can absorb financial and real economic shocks or unexpected events while continuing to perform its functions.

Thus, to determine macroeconomic stability we should use an integrated approach that combines achieving financial stability along with raising production through innovation.

As Zhalilo (2002) notes, it is clear that this process is a complex multi-level system of economic relations on "reification" of knowledge, which is characterized by specific patterns and relationships. Given the significant and sometimes decisive role of innovation processes in the modern economy, defining and including these features is a prerequisite for ensuring effectiveness of the state economic strategy.

After Sohnych (2012), the main features of innovation processes are: increasing saturation of scientific and innovative products (ideas, patents, 
information, etc.) and many innovative ideas (new competitive products or services), and a new nature of competition, the main feature of which is possibility of cooperation between competitors in developing and implementation of innovation.

\section{Measures of the state to support innovation development}

In world practice, there are invented many tools to support innovation with which the state implements its functions, required in this area. Several groups are among them:

Direct financial support for innovation processes:

- directly funding creation of new industries, high-tech productions, etc. from the state budget, including state-owned enterprises

- initiate creation and funding the research programs, research centers through competitive selection

- provide interest free or concessional loans and grants

- public support for innovative products

- subsidies from state budget for certain sectors, industries or technologies

- compensation of banking percent in whole or in part, in case of channeling loans to finance investments in innovative technological changes

- state subsidies for leading research centers and scientists

- compensation for research institutions the costs on establishing informational provision and support (connection to the worldwide web "Internet", organizing subscriptions on foreign editions for libraries, etc.).

Fiscal incentives for innovators are as follows:

- cutting corporate income tax

- tax credit for innovative enterprises

- reducing profit before tax through excluding from it the value of research or development of new technologies

- exemption from certain payments to budget

- tax exemption on income that is received by owners of property rights on innovation and venture capital firms

- delay in paying import duty or exemption in case of import of goods for innovative projects

- preferential depreciation method for companies identified as innovative.

Other legal, infrastructural, economic and political instruments to support innovation are:

- improving legislation on copyright, patent relations

- introduction certification and standards that encourage innovative consumer products, food products of high quality, new medical, 
construction, telecommunications, recreational, tourism and transport services

- development and support of education in the country: schools of general education, universities, specialized vocational training, lifelong learning system and retraining of workforce, profile of training courses and management

- temporary permit of monopoly producer on innovative products and innovative technologies for innovator, or, conversely, limiting monopoly, which reduces the cost of establishing new producers of goods or services

- creation of national information infrastructure, access to information networks and databases, libraries

- providing enterprises with government contracts to ensure reimbursement for financing innovation

- performing state lobbying for Ukrainian manufacturers of innovative products internationally, using appropriate trade regime and exchange rate.

For long-term forecasting the progress of science and technology in developed countries (Japan, Germany, UK, USA, France and many others) the "Foresight" (prediction) methodology is widely used. Foresight is established to be one the most effective tool to identify priorities in science and technology.

Today Ukraine is represented in a number of indices that assess technology and innovation competitiveness and provide their rating. These include the Global Competitiveness Index of the World Economic Forum in Davos, Knowledge Economy Index of the World Bank and General Innovation Index of the European Innovation Scoreboard (GII), as measured by EuroINNO supported by the European Commission.

The Global Competitiveness Index is currently the most comprehensive meter on competitiveness that summarizes expert opinions of over 1,300 independent experts from different countries and areas, and official statistics from countries. It is based on calculating 12 sub-indices, grouped into three units based on dominance of development factor: basic conditions for development, factors, catalysts or intensifiers of performance and factors of innovation and development.

According to the latest report of the World Economic Forum on global competitiveness in 2012-2013, between 144 countries Ukraine ranked 73-rd place against 82-nd in 2011-2012. The rank is dominated by Switzerland, Singapore and Finland, which are the top three. Russia and Kazakhstan are ahead of Ukraine in terms of competitiveness, ranking respectively 67-th and 51-st place in the overall ranking.

As a result of economic and political turmoil, Ukraine lost 16 positions in 2009-2010, but in 2011-2012 economical conditions have improved, allowing the country to climb up 7 positions in the ranking. And according to report of the World Economic Forum on global competitiveness for 2012-2013 Ukraine has risen by another 9 positions, continuing to demonstrate its main competitive advantages - education and market capacity. 
An important component of EU policy in scientific-innovation and pure innovation area was creation of a special system of European Innovation Scoreboard (EIS). The system of indicators allows fixing the situation in each sector - as in every country and in the whole EU, to form scale estimates, tracking trends (directions) for key indicators. Analysis of the obtained information allows developing measures in practical assistance for those countries that have relatively low values of indicators taken as reference.

This year Ukraine ranked 63 in the overall ranking. Only with 0.1 point ahead of us are Macedonia, Moldova, Russia and Romania - have taken 50, 51 and 52 places in ranking respectively. Poland has risen up to 44-th position.

As noted in report, the strengths of Ukraine are related to development of knowledge (30-th place), human capital (48-th place), and business development (51-st place). Imperfect institutions (117-th), infrastructure (98th), the internal market development indicators (68-th) and results of creative activity (83-rd) prevent innovation.

TABLE 1. RATING OF COUNTRIES BY INNOVATION INDEX IN 2012

\begin{tabular}{lccccc}
\hline \hline No. & Country & Index & No. & Country & Index \\
\hline 1 & Switzerland & 68.2 & 16 & Malta & 56.1 \\
\hline 2 & Sweden & 64.8 & 17 & Israel & 56.0 \\
\hline 3 & Singapore & 63.5 & 18 & Iceland & 55.7 \\
\hline 4 & Finland & 61.8 & 19 & Estonia & 55.3 \\
\hline 5 & United Kingdom & 61.2 & 20 & Belgium & 54.3 \\
\hline 6 & Netherlands & 60.5 & 21 & South Korea & 53.9 \\
\hline 7 & Denmark & 59.9 & 22 & Austria & 53.1 \\
\hline 8 & Hong Kong & 58.7 & 23 & Australia & 51.9 \\
\hline 8 & Ireland & 58.7 & 24 & France & 51.8 \\
\hline 10 & USA & 57.7 & 25 & Japan & 51.7 \\
\hline 10 & Luxembourg & 57.7 & 26 & Slovenia & 49.9 \\
\hline 12 & Canada & 56.9 & 27 & Czech Republic & 49.7 \\
\hline 13 & New Zealand & 56.6 & 28 & Cyprus & 47.9 \\
\hline 14 & Norway & 56.4 & 29 & Spain & 47.2 \\
\hline 15 & Germany & 56.2 & 30 & Latvia & 47.0 \\
\hline Source: Combinat
\end{tabular}

Source: Combined by authors, basing on INSEAD, 2012.

Something different from the European system for measuring innovation development in regions is in the United States. Consolidated Index of Innovation (PII, Portfolio innovation index) for American regions (states and counties) consists of four blocks, each of which is assigned with different weights: human capital (30\%), economic dynamics (30\%), productivity and employment (30\%) and welfare (10\%). Each block consists of 5 to 7 indicators that reflect its content.

Noteworthy is annual Knowledge Economy Index - a composite index that reflects level of economy's development based on knowledge in countries and regions of the world, calculated by method from the World Bank. The basis for calculation of this Index is the Knowledge Assessment Methodology (KAM), developed by the World Bank, which includes a set of 109 structural and qualitative indicators, grouped into four main groups. In 2012, the study covered 146 countries and territories. States use index to analyze particular 
issues in their economic policies and measure readiness for transition to a development model based on knowledge.

Following results of 2012, Ukraine ranked 56-th place among 146 countries in the Knowledge Economy Index ranking in 2012. The top five rankings were: Sweden, Finland, Denmark, Netherlands and Norway.

From the above guidance, monitoring of innovation is one of the key issues in analysis of innovation, assessing its effectiveness as in organization and in the economy as a whole, which requires serious analysis of existing methods and conditions for their usage. During last 10-20 years the world practice leverages several key methodologies to assess development of innovative activity, namely:

1) European innovation scale (EIS)

2) System of performance indicators of innovation by OECD

3) System of the World Economic Forum

4) Knowledge Assessment Methodology (KAM) by the World Bank.

Effectiveness of these techniques is confirmed by practical testing in countries with different levels of economic, social and political relations, as well as other distinctive features.

TABLE 2. KNOWLEDGE ECONOMY INDEX:

UKRAINE AND SOME EUROPEAN COUNTRIES IN 2009-2010

\begin{tabular}{|c|c|c|c|c|c|c|}
\hline \multirow[t]{2}{*}{ Country } & \multirow[t]{2}{*}{ KEI } & \multirow{2}{*}{$\begin{array}{l}\text { Country in } \\
\text { ranking }\end{array}$} & \multicolumn{4}{|c|}{ Country under index components (sub-indexes): } \\
\hline & & & $\begin{array}{l}\text { Economic } \\
\text { incentives and } \\
\text { institutions }\end{array}$ & $\begin{array}{c}\text { Innovation } \\
\text { system }\end{array}$ & $\begin{array}{c}\text { Education } \\
\text { and HR }\end{array}$ & ICT \\
\hline Denmark & 9.52 & 1 & 2 & 5 & 1 & 9 \\
\hline Sweden & 9.51 & 2 & 8 & 2 & 7 & 2 \\
\hline Finland & 9.37 & 3 & 10 & 3 & 3 & 16 \\
\hline UK & 9.1 & 7 & 12 & 11 & 15 & 6 \\
\hline Germany & 8.96 & 12 & 14 & 18 & 19 & 5 \\
\hline Estonia & 8.42 & 21 & 20 & 36 & 22 & 12 \\
\hline Israel & 8.01 & 26 & 26 & 9 & 42 & 39 \\
\hline $\begin{array}{l}\text { Czech } \\
\text { Republic }\end{array}$ & 7.97 & 28 & 27 & 31 & 24 & 34 \\
\hline Lithuania & 7.77 & 31 & 31 & 45 & 17 & 29 \\
\hline Poland & 7.41 & 37 & 37 & 38 & 29 & 42 \\
\hline Romania & 6.43 & 47 & 45 & 60 & 48 & 54 \\
\hline Ukraine & 6 & 51 & 80 & 56 & 26 & 62 \\
\hline Russia & 5.55 & 60 & 127 & 41 & 38 & 54 \\
\hline Turkey & 5.55 & 61 & 44 & 55 & 87 & 75 \\
\hline Kazakhstan & 5.05 & 72 & 70 & 92 & 39 & 79 \\
\hline Belarus & 4.93 & 73 & 137 & 58 & 30 & 80 \\
\hline
\end{tabular}




\section{Conclusion}

An innovative way of development can be achieved realistically in the case of certain conditions, including the following: qualitative assessment of innovation potential, particularly in the regional and sectoral dimensions, development of conceptual frameworks and mechanisms of innovative development, forming infrastructure that is able to provide a decent start for innovation process, combining efforts of government, business, research and education sector, the public as a whole corporate object of self-development.

Thus, the main goal of public innovation policy should be to create socioeconomic, organizational and legal conditions for effective reproduction, development and usage of scientific and technical potential, introduction of advanced environmentally friendly, energy-saving technologies, production and marketing of new competitive products.

\section{References}

Economy, No. 12, pp. 28-31. Access mode: http://archive.nbuv.gov.ua/portal/Soc_Gum/inek/ 2012_12/28.pdf

INSEAD, WIPO, 2012. The global innovation index 2012 [Глобальний індекс інновацій 2012], in Ukrainian, Retrieved 20.06.2013 from http://www.csr-ukraine.org/interes/dosludjennya _insead_global_undeks.html

Kallaur, P., 2008. "Developing a system for monitoring and assessing financial stability of the Republic of Belarus," Bank Bulletin [Bankavskiy Vesnik], in Russian, No.6, pp.4-8

Kozyuk, V., 2007. "Monetary aspects of views on issue to ensure global financial stability," Bulletin of the NBU [Byulleten NBU], in Russian, No.4(134), pp.34-39

Shinazi, G., 2005. Preserving financial stability [Sohranenie finansovoy stabilnosti], in Russian, International Monetary Fund

Sohnych, A., Irtyscheva, I., 2012. "Innovation under economic transformation," Theoretical and practical aspects of economy and intellectual property [Теоретичні і практичні аспекти економіки та інтелектуальної власності], in Ukrainian, Vol.2(1), pp.14-18 Retrieved 20.06.2013 from http://archive.nbuv.gov.ua/portal/soc_gum/Tpaeiv/2012_1_2/2.pdf

Ukrainian institute for scientific-technical and economic information Innovation, 2013. "Innovation capacity and technological readiness of Ukrainian economy in international comparisons [Інноваційна спроможність та технологічна готовність української економіки у міжнародних порівняннях], in Ukrainian, Retrieved 20.06.2013 from http://www.uintei.kiev.ua/viewpage.php?page_id $=432$

Ukrainian institute for scientific-technical and economic information Innovation, 2013. Place of Ukraine in the Global Competitiveness Index in 2012-2013 [Місце України за Глобальним індексом конкурентоспроможності у 2012-2013pp.], in Ukrainian, Retrieved 20.06.2013 from http://www.uintei.kiev.ua/viewpage.php?page_id=492

Ukrainian institute for scientific-technical and economic information Innovation, 2013. World experience in the innovative progress monitoring [Світовий досвід моніторингу Інноваційних досягнень], in Ukrainian, Retrieved 20.06.2013 http://www.uintei.kiev.ua/viewpage.php?page_id=537

Zhalilo, Ya., 2002. Prospects for innovation development of Ukraine [Перспективи інноваційного розвитку україни], in Ukrainian, Retrieved 20.06.2013 http://old.niss.gov.ua/Table/Zhalilo21/oo3.htm 